MOVERS

\section{Gary Borisy, director and chief executive, Marine Biological Laboratory, Woods Hole, Massachusetts}

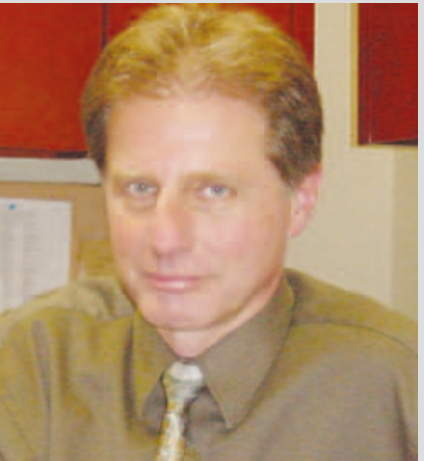

2003-06: Associate vicepresident for research, Northwestern University, Evanston, Illinois 2000-06 Leslie B. Arey professor of cellular and molecular biology, Northwestern University, Illinois 1968-2000 Professor of molecular biology and zoology, University of Wisconsin, Madison

Gary Borisy's career has been propelled by motion. When the University of Chicago biochemistry major realized no one knew how chromosomes move during mitosis, he embarked on a lifelong quest to document basic cellular movements. Little did he know that his scientific journey would bring him repeatedly to the Marine Biological Laboratory (MBL) in Woods Hole, Massachusetts.

Doing his $\mathrm{PhD}$ research at Chicago, Borisy discovered that tubulin, the protein that makes up microtubules, is key to the cell division process. But it was an MBL summer course that spurred him to unlock more cell secrets. He learned to isolate the fibres, called mitotic spindles, that distribute chromosomes during cell division. "Once you work a summer in Woods Hole, you want to come back," he says of the interactive, camp-like escape for scientists.

Mentors, however, advised him to explore other areas. Hugh Huxley, a molecular biologist at the UK Medical Research Council in Cambridge who had worked on the mechanism of muscle contraction, welcomed Borisy as a postdoc. The time he spent in Huxley's lab gave Borisy a solid footing in the discipline of structural biology.

Borisy then went to the University of Wisconsin in Madison, but managed to maintain a summer laboratory at Woods Hole for five years to study cytoskeleton formation.

After a one-year sabbatical back at Cambridge, Borisy shifted his approach from the test tube to the cell. He went to the Weizmann Institute of Science in Rehovot, Israel, to collaborate with pioneers of the then-nascent fluorescent techniques combined with subcellular imaging. "That was a major turning point for me," says Borisy. A decade of in vivo cell-division work included documenting how cells crawl.

Next, Borisy went to Northwestern University, where he was soon made associate vice-president of research. The rave reviews he won for assembling a coalition of four Chicago-area institutions to advance health technologies led an MBL search committee to appoint him as director and chief executive. At first reluctant to be a full-time administrator, Borisy was swayed by his affection for MBL, according to John Dowling, president of the MBL corporation.

Borisy now looks forward to drawing on MBL's strengths in ecosystems, microbial evolution and cell dynamics, while enhancing the educational and collaborative opportunities. In doing so, he'll be responsible for maintaining the adminfree environment he's enjoyed for so many years - one of the qualities that makes MBL a scientific Shangri-La.

Virginia Gewin

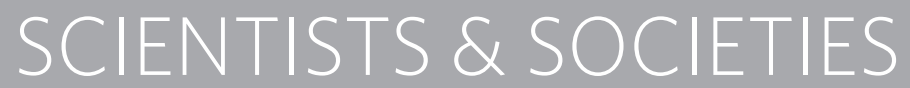

Networks work
When I chose to do a PhD project in computational biology, my supervisor baulked. "Do you really want to work for three years on a computer?" he asked. He'd made a valid point: I needed to assess the best way to shape my path. I decided a multidisciplinary preparation was a must. I was soon to learn that international organizations of students and researchers can provide a valuable

Given that my project focuses on the structure-function relationship in proteins, I needed experience with the wet-lab stuff of biochemistry and X-ray crystallography. Ideally, this would help me attain a broader vision and a better understanding of the structures and functions of interest to me.

I started to explore the possibility of becoming a visiting scientist outside Italy, by looking through the usual job ads. I thought it would be easy to find something. I wasn't expecting a salary, only a place receptive to hosting an enthusiastic Italian trainee in protein biochemistry. But I sent out countless $\mathrm{CV}$ and referee letters with no result.

My quest changed dramatically when I started to consider it from another perspective: any boss would rather find an employee through a personal contact than by e-mail. Marco Quarta, chairman of the Young European Biotech Network (YEBN), of network for $\mathrm{PhD}$ project needs. which I'm a member, advised me to send a message to members abroad, who would post it to their local networks

I was intrigued. Although I chaired a task force for the YEBN, and recognized the value of its networking resources for teaching skills such as teamwork and project management, I hadn't thought of using it this way. Yet this group of professionals with different scientific backgrounds offered the potential for interesting collaborations.

Just one day after my posting I got an interesting proposal. If I had considered the 'network opportunity' earlier I would have saved some precious time.

I spent nine months at the University of Limerick in Ireland, in a biochemistry laboratory where the activities ranged from the identification and expression of promising genes encoding bacterial proteases and inhibitors, to the crystallization and computational work necessary to study proteins. Now I'm back in Milan in my home lab.

My time in Ireland was invaluable. I studied the practical issues behind protein structure determination and characterization. I know that my time there enriched my PhD experience and provided me with an additional skill set that will aid my career.

Denis Bilotta is a molecularmodelling PhD student at the University of Milano-Bicocca, Italy.

\section{GRADUATE JOURNAL}

\section{Goooaaall!! A PhD!}

These are exciting times for a scientist. On the day the Netherlands, my home country, defeated Serbia and Montenegro in the World Cup, I wrote two-thirds of the 'results' section of a paper. Both were major stepping-stones.

I've been spending days away from the lab in order to write the two papers that will form the heart of my thesis. In between paragraphs, I'm also revelling in the opening-rounds drama of the World Cup. Four years ago, the World Cup didn't present nearly so much of a distraction. To begin with, Holland wasn't playing. Moreover, I was a young graduate student lacking any sense of urgency. A few mornings away from the lab weren't going to change the outcome of my PhD.

This time around, I have deadlines to meet. So - except for taking two hours off to put on my orange wig, trot down to the pub with the other Europeans in town and root for Holland on match days - I have to content myself with following the games on my laptop while I write.

My PhD work has been intense. Not every day has the drama of a championship match, but with the final stage of my research in sight it's time to step it up. This month is the culmination of four years of preparation - for the Netherlands, who are about to face the second round as I write, and for me, who needs to commit a few more experiments to paper to form a thesis. Wish us both luck.

Milan de Vries is a molecular-biology graduate student at the Massachusetts Institute of Technology. 